\title{
Inovasi Virtual Exhibition Masa Depan
}

\author{
Indira Khairunnisa ${ }^{1}$, Adinda Dhiya Hasna ${ }^{2}$, Heidy Bherti Kharoline ${ }^{3}$, Any Ariani Noor ${ }^{4}$ \\ 1,2,3,4 Politeknik Negeri Bandung, Indonesia. indira.khairunnisa.upw18@polban.ac.id
}

\begin{abstract}
ABSTRAK
Industri MICE (Meeting, Incentive, Conference, and Exhibition) merupakan bagian dari sektor pariwisata yang mengalami kerugian cukup besar akibat wabah Covid-19. Melihat hal ini para ahli di bidang MICE berusaha menciptakan inovasi-inovasi yang dapat mempertahankan keberlangsungan industri MICE di masa pandemi. Salah satunya dengan memanfaatkan teknologi dalam menciptakan aplikasi berupa pameran virtual. Perkembangan yang terus terjadi dalam dunia teknologi informasi menjadi alasan dibuatnya penelitian ini, dengan tujuan menemukan peluang yang dapat menjadi acuan para pelaku kegiatan MICE dalam berinovasi, serta mengembangkan kegiatan MICE khususnya virtual exhibition di masa depan dengan adanya teknologi Virtual Reality 360. Penelitian ini mengumpulkan hasil data berupa riset serta referensi kepustakaan yang mendukung teori terkait dengan masalah yang menjadi fokus dalam penelitian ini. Berdasarkan hasil analisis ditemukan bahwa virtual exhibition menjadi kecendrungan di masa pandemi saat ini. Virtual exhibition kemudian dikembangkan lebih jauh lagi ke dalam teknologi Tiga Dimensi (3D). Dengan memanfaatkan perkembangan Teknologi, seperti google cardboard dapat menjadi sarana pendukung hadirnya sebuah inovasi pada virtual exhibition berupa implementasi teknologi virtual reality 360. Dengan adanya kemudahan dalam memperoleh alat pendukung ini, diharapkan dapat memberikan peluang kepada para ahli dalam industri MICE untuk mengembangkan lebih jauh lagi aplikasi virtual exhibition dengan implementasi teknologi virtual reality 360.
\end{abstract}

Kata Kunci: MICE, Pameran Virtual, Virtual Reality 360

\begin{abstract}
The MICE (Meeting, Incentive, Conference, and Exhibition) industry is part of the tourism sector that has suffered significant losses due to the Covid-19 outbreak. Seeing this, experts in the field of MICE are trying to create innovations that can sustain the MICE industry during a pandemic. One of them is using technology to creat applications in the form of a virtual exhibition. The development that continues to occur in the world of information technology is the reason for this research, with the aim of finding opportunities that can be a reference for MICE activity actors in innovation, as well as developing MICE activities, especially virtual exhibitions in the future with the Virtual Reality 360 technology. This study collects data in the form of research and literature references that support theories related to the problem that is the focus of this research. Based on the results of the analysis, it was found that virtual exhibitions are becoming a trend during the current pandemic. The virtual exhibition is then further developed into Three Dimensional (3D) technology. By utilizing technological developments, such as google cardboard, it can be a means of supporting the presence of an innovation at a virtual exhibition in the form of the implementation of 360 virtual reality technology. By obtaining this supporting tool, it is hoped that it can provide opportunities for experts in the MICE industry to further develop virtual exhibition applications. with the implementation of 360 virtual reality technology.
\end{abstract}

Keywords: MICE, Virtual Exhibition, Virtual Reality 360.

Diterima: 10 Feb 2021, Direvisi: 15 Feb 2021, Dipublikasi: 15 Feb 2021 


\section{PENDAHULUAN}

Wabah covid-19 yang berawal dari kasus lokal di Wuhan, China, kini sudah menyebar ke berbagai negara di dunia, salah satunya Indonesia. Adanya wabah ini bukan hanya berdampak pada sektor kesehatan, namun berbagai sektor seperti ekonomi, manufaktur, transportasi, perdagangan hingga pariwisata mengalami kerugian. Dalam hal ini pemerintah berusaha menanggulangi agar wabah ini tidak semakin menyebar dengan memberikan peraturan berupa protokol kesehatan, hingga diberlakukannya PSBB (pembatasan sosial bersekala besar). Peraturan yang di berlakukan ini, akhirnya mengharuskan segala kegiatan yang berhubungan dengan orang banyak terpaksa harus di hentikan.

Sebagai salah satu sektor perekonomian, pariwisata merupakan bagian dari penyumbang devisa terbesar bagi sejumlah negara, termasuk Indonesia. Kegiatan pariwisata merupakan sektor ekonomi yang melibatkan banyak orang dengan beragam aktivitas di dalamnya. Sehingga, dengan adanya kondisi seperti saat ini, pariwisata menjadi salah satu sektor yang mengalami kerugian yang cukup besar. Salah satu kegiatan pariwisata yang biasa melibatkan banyak orang adalah MICE (Meeting, Incentive, Conference, and Exhibition).

MICE merupakan usaha dengan kegiatan memberi jasa pelayanan bagi suatu pertemuan sekelompok orang (negarawan, usahawan, cendekiawan, dan sebagainya) untuk membahas masalah-masalah yang berkaitan dengan kepentingan bersama (Pendit, 1999).

Melihat hal ini, para ahli yang bergerak di industri MICE merasa perlu untuk menciptakan inovasi baru agar industri ini tidak berhenti begitu saja. Beragam aplikasi video conference telah dibuat untuk mewadahi kegiatan MICE dalam bentuk online, seperti rapat atau pertemuan penting yang melibatkan banyak orang. Namun hal ini di rasa masih belum cukup, karena aplikasi video conference dianggap belum mampu menampung keberlangsungan kegiatan insentif dan pameran. Sehingga para ahli masih perlu memutar otak untuk menjadikan masalah ini sebagai kesempatan untuk mengeluarkan ide nya yang bisa dimanfaatkan dalam industri MICE.

Di negara maju seperti Hongkong sebuah aplikasi yang dinamakan eventXtra telah diluncurkan. Sesuai dengan namanya aplikasi ini menyediakan kebutuhan dalam menangani event, utamanya berupa pameran online. Pada aplikasi ini konsumen dapat mengetahui jalannya acara dan berbagai produk yang ditawarkan hanya dengan melihat layar komputer, menanyakan hal yang ingin diketahui secara langsung, bahkan dapat bertransaksi selama acara berlangsung (Beribe, 2020). Inovasi aplikasi seperti inilah yang saat ini sedang dibutuhkan oleh industri MICE.

Sebagai negara yang mengandalkan sektor pariwisata dalam penambahan devisanya, Indonesia tidak mau ketinggalan dalam kesempatan ini. Sebuah aplikasi virtual terbarukan dengan nama virtualevent.id yang diluncurkan sebagai alternatif pelaksanaan pameran online. Aplikasi virtual ini diciptakan dengan mempertimbangkan kondisi pandemi yang belum menentu hingga saat ini, sehingga mengancam keberlangsungan industri pariwisata secara umum, dan MICE event secara khusus. Aplikasi virtual ini juga memang sengaja dibuat bukan hanya untuk menangani kegiatan MICE berupa meeting dan conference, uniknya aplikasi ini juga dapat menyelenggarakan kegiatan pameran yang selama ini masih dianggap sulit apabila dilakukan secara online (Widhiyanto, 2020).

Berdasarkan latar belakang, studi difokuskan pada analisis inovasi dalam virtual exhibition dengan membandingkan aplikasi virtual EventXtra yang dikembangkan di Hongkong dengan virtualevent.id yang mulai dikembangkan di Indonesia. Hasil kajian dapat digunakan sebagai acuan para pelaku kegiatan MICE dalam berinovasi, serta mengembangkan kegiatan MICE khususnya virtual exhibition di masa depan dengan adanya teknologi Virtual Reality 360. Diharapkan dengan adanya artikel ini dapat memperkaya hasanah pengetahuan tentang kepariwisataan secara teori dalam bidang virtual exhibition, serta mengetahui manfaat adanya virtual exhibition sebagai bagian dari kemajuan teknologi dalam bidang pariwisata.

\section{KAJIAN PUSTAKA \\ EventXtra}

Perkembangan teknologi IT saat ini sedang banyak digemborkan. Berbagai kegiatan industri juga memanfaatkan situasi ini sebagai alternatif selama pandemi berlangsung, salah satunya dalam industri pariwisata. Pemanfaatan teknologi informasi dalam industri MICE sudah mulai dikembangkan di beberapa negara. Hongkong menjadi salah satu negara yang dipandang sebagai pelopor dalam lahirnya inovasi virtual event. Pasalnya sejak tahun 2014 Hongkong telah membuat perusahaan startup yang bertujuan untuk memfasilitasi para pelaku industri MICE dalam menjalankan manajemen acara secara digital. 
Kemajuan dalam dunia MICE ini dilanjutkan dengan keluarnya inovasi beruba platform yang diberi nama EventXtra. Sum Wong selaku co- founder dari EventXtra mengatakan bahwa aplikasinya dapat mewadahi pelaksanaan kegiatan pameran secara virtual, Wong juga mengatakan bahwa EventXtra mampu memberikan pengalaman interaktif dan menunjukan data analisis acara dengan lebih efisien. Pada proses perkembangannya, EventXtra telah membukukan pertumbuhan pendapatannya hingga mencapai $300 \%$ hanya dalam setengah tahun setelah inovasi berupa pameran virtual diluncurkan, hal ini menunjukan bahwa pameran virtual dapat menjadi sebuah tren besar di masa depan (Nurcahyadi, 2020).

\section{Virtualevent.id}

Melihat adanya perkembangan teknologi yang terus terjadi, Indonesia menjadikan kesempatan ini juga sebagai peluang besar dalam industri MICE terbarukan, dengan membuat sebuah platform virtual event yang diberi nama Virtualevent.id. Aplikasi event virtual ini kenalkan fitur lengkap yang membantu pelaku industri, khususnya penyelenggara event agar dapat menyelenggarakan event secara virtual dengan cara yang mudah digunakan, efektif dan efisien terutama di masa Pandemi COVID-19. Virtualevent.id merupakan aplikasi karya anak bangsa, menggunakan Bahasa Indonesia didukung kantor dan tim di Indonesia sehingga lebih siap dan cepat dalam kordinasi. Virtualevent.id memastikan para penyelenggara acara akan mampu menyelenggarakan acara digitalnya sendiri, dengan dibantu tim ahli yang siap membantu (Wartaekonomi, 2020).

Aplikasi virtualevent.id yang diluncurkan pada 9 september 2020 ini, disebut sebagai jawaban atas keresahan pelaku MICE di Indonesia dalam penyelenggaraan pameran di masa pandemi. Selaras dengan perkataan Jul Darmawan selaku CEO Virtualevent.id bahwa aplikasi berbahasa Indonesia karya anak bangsa ini memungkinkan penyelenggaraan konferensi, kongres hingga pameran secara digital. Jul Darmawan juga menyebutkan bahwa aplikasi buatannnya ini dapat membantu secara menyeluruh dalam proses kegiatan MICE berlangsung, mulai dari persiapan acara, saat acara, layanan bantuan hingga berakhirnya acara dengan memberikan laporan dan analisa data mengenai acara yang di selenggarakan (Widhiyanto, 2020).

\section{Virtual Exhibition}

Pameran virtual adalah kumpulan replika digital dari peristiwa atau objek nyata yang dikembangkan dengan bantuan alat multimedia dan virtual reality yang menghasilkan lingkungan simulasi di komputer, dan disampaikan melalui web sehingga pengguna akan mendapatkan kepuasan yang sama seperti yang dilihat atau digunakan. benda fisik di berbagai daerah. Perbedaan antara pameran online dan virtual sangat tipis. Semua pameran virtual adalah pameran online tetapi tidak sebaliknya. Biasanya semua pameran virtual akan menyediakan simulasi lingkungan nyata menggunakan alat realitas virtual yang sedikit lebih sulit, mahal dan memakan waktu untuk mengembangkannya daripada pameran online sederhana. Tidak seperti pameran tradisional, pameran ini dapat dilihat tanpa biaya, dengan kenyamanan dan zona waktu sendiri (Khoon and Ramaiah, 2008).

Berdasarkan pemaparan ini, dapat disimpulkan bahwa kedua aplikasi memiliki fungsi dan manfaat yang tidak jauh berbeda. Hanya saja dalam pengembangannya aplikasi asal Hongkong lebih dulu diluncurkan, sehingga kita sudah bisa melihat perkembangannya secara nyata. Dengan adanya kedua aplikasi ini, menandakan bahwa adanya virtual exhibition adalah nyata dalam perkembangan teknologi di bidang MICE masa depan. Pemaparan ini juga memberikan gambaran peluang teknologi informasi yang dapat dikembangkan dan diimplementasikan pada aplikasi yang telah ada saat ini.

\section{METODOLOGI PENELITIAN}

Penelitian ini mengumpulkan hasil data berupa riset serta referensi kepustakaan yang mendukung teori terkait dengan masalah yang menjadi focus dalam penelitian.

\section{HASIL DAN PEMBAHASAN \\ Kondisi MICE di Masa Pandemi}

MICE sebagai salah satu kegiatan pariwisata memiliki potensi dalam penularan covid-19. Dengan adanya pembatasan yang diberlakukan selama pandemi, menyebabkan sektor pariwisata mengalami kerugian, begitu pula kegiatan MICE. Berdasarkan data dari Indonesia Event Industry Council (Ivendo), pada tahun 2017 industri MICE dapat menghasilkan pendapatan Produk Domestic Bruto (PDB) hingga mencapai total 7,8 miliar dolar AS dan menciptakan 278.000 lapangan pekerjaan. Hal ini 
berbanding terbalik dengan kondisi sekarang, saat ini MICE memiliki potensi kerugian akibat pandemic covid-19 berkisar 2,69 triliun hingga 6,94 triliun rupiah. Data ini juga menyebutkan sekitar 96,43\% acara di 17 provinsi harus ditunda, dan $84,20 \%$ lainnya harus dibatalkan. Serta berdampak pada 90.000 pekerja (Shofihara, 2020).

Dalam mengatasi situasi yang sedang terjadi ini, kehadiran sebuah inovasi dalam bidang MICE berupa aplikasi virtual yang dapat mewadahi kegiatan virtual exhibition. Hal ini tentu mengalami banyak pro dan kontra, pasalnya pameran yang dilaksanakan secara virtual saat ini masih di anggap hal yang tabu dan sulit dalam pelaksanaan nya. Selaras dengan ungkapan Iqbal Alan Abdullah selaku Ketua Umum Dewan Pimpinan Pusat Indonesia Congress \& Convention Association (INCCA) yang menyebutkan bahwa pameran tidak bisa dilakukan secara online. Menurutnya, pameran harus diadakan offline karena akan mempertemukan pengunjung dengan produk secara langsung (Aditya, 2020).

\section{Hadirnya Tren Virtual Exhibition}

Saat ini virtual exhibition sedang menjadi tren di Indonesia, berbagai acara menjadi bukti adanya pengembangan yang semakin luas dalam pemanfaatan kegiatan virtual utamanya di masa pandemi. Seperti pameran yang telah terlaksana pada 20-28 oktober 2020 dengan mengusung tema pelestarian dongeng dan cerita rakyat. Pameran virtual yang digagas oleh seniman dan sutradara pertunjukan, Rama Soeprapto ini juga mendapatkan dukungan dari Kementerian Pariwisata dan Ekonomi Kreatif, dikatakan bahwa Kemenprarekraf sangat mendukung kegiatan yang memanfaatkan platform digital dalam pelaksanaannya (Aulia, 2020).

Dukungan yang diberikan pemerintah dalam menyelenggarakan pameran secara virtual ini memberikan kesempatan bagi para ahli di bidangnya untuk mengembangkan kemampuannya lebih jauh lagi, salah satu wujud nyata yang saat ini mulai digunakan di Indonesia dalam mendukung kegiatan pameran secara virtual adalah dengan menerapkan teknologi 3D pada pelaksanaannya. New Normal Travel Fair 2020 merupakan pameran virtual yang telah mengamplikasikan teknologi 3D dalam pelaksanaan kegiatannya. Fairtual, selaku organisasi yang mengusung hadirnya kegiatan ini mengatakan alasannya menggunakan teknologi ini dengan tujuan membuat detail produk semakin jelas dilihat oleh para peserta. Pameran yang diselenggarakan berskala internasional ini merupakan pertama sekaligus terbesar di Indonesia, dengan diikuti oleh beberapa pelaku industri pariwisata serta di hadiri oleh Menteri Pariwisata dan Ekonomi kreatif secara virtual. Event ini juga menjelaskan bahwa berbagai aktivitas dapat dilakukan dalam platform Fairtual mulai dari bertransaksi secara virtual, berinteraksi dengan customer service secara virtual di setiap booth hingga berkeliling ke seluruh areal hall virtual (Wijayaka, 2020).

Pengembangan teknlogi informasi yang terus terjadi di industri MICE ini, membuat penulis menemukan adanya sebuah peluang baru yang dapat dikembangkan dalam kegiatan virtual exhibition, yaitu sebuah konsep dengan pemanfaatan kecanggihan teknologi berupa Virtual Realiy 360. Virtual reality merupakan sebuah teknologi yang membuat pengguna dapat berinteraksi dengan lingkungan dalam dunia maya yang disimulasikan oleh komputer, sehingga pengguna merasa berada di dalam lingkungan tersebut (Putra, Wahyudi and Tumilaar, 2018). Saat ini VR 360 sudah mulai banyak digunakan dalam kehidupan sehari-hari, seperti dalam game, uji coba pilot, pun dalam bidang pariwisata seperti virtual tour. Kementerian Pariwisata dan Ekonomi Kreatif (Kemenparekraf) juga sudah menawarkan VR 360 sebagai solusi wisata di masa pandemi, dengan mengakses website DirumahAja360 (Priambo, 2020). Sehingga dengan adanya dukungan ini, bukan hal yang mustahil jika di masa depan aplikasi virtual exhibition juga menggunakan teknologi VR 360.

Inovasi ini bukanlah hal baru, tetapi masih merupakan cara yang efektif dalam mempromosikan, mengkomunikasikan, dan menjual. Dalam proses pelaksanaannya booth akan dibuat sesuai tema produk dan ide penyelenggara. Booth dibangun, didekorasi dan diprogram dalam ruang virtual reality VR360. Intinya, stan dibuat dari gambar 360 dan diprogram untuk memungkinkan untuk menyeberang, mengunjungi, melihat dan menambahkan informasi, gambar 2D dan 3D untuk memungkinkan tampilan, interaksi terbatas dan pembelian. Teknologi yang digunakan adalah 3D, artinya booth, item, dan ruangan dalam aplikasi semuanya 3D. Informasi tambahan dapat berupa Media, atau informasi dalam format lain seperti teks, suara dan pemirsa dapat melakukan perjalanan, menonton, dan berinteraksi sendiri di ruang virtual 3D (XXmorecreative, 2020). 
Saat ini sudah banyak alat yang mendukung kehadiran teknologi VR360 agar dapat lebih mudah di akses, salah satu yang mudah dijangkau yaitu google cardboard. Aplikasi Google Cardboard adalah sebuah headset yang dirakit atau do-it-yourself (DIY) dari potongan kardus, dibentuk dan dilipat sedemikian rupa sehingga menjadi bentuk kacamata. Google Cardboard menghadirkan pengalaman yang begitu nyata bagi siapa saja dengan cara yang sederhana dan terjangkau untuk merasakan sensasi berada di lingkungan sesuai gambar yang ditampilkan (Kompas.com, 2014). Sehingga dengan adanya hal ini dapat memudahkan terwujudnya perkembangan virtual exhibition dengan teknologi VR360 untuk dikembangkan menujujadi kegiatan yang dapat dilaksanakan dimana saja serta menjadi sebuah inovasi yang dapat diimplementasikan dan dikembangkan di masa depan.

\section{Implementasi Virtual Reality pada Aplikasi Virtual Exhibition}

Pada proses implementasi kegiatan ini Pelaku Industri MICE berperan dalam pemanfaatan aplikasi yang sudah ada dengan alat bantu yang dapat mendukung terselenggaranya acara pameran virtual, tentunya dibarengi dengan adanya bantuan dari pelaku bidang IT dalam proses pembuatan implementasi konsep VR 360 pada aplikasi virtual exhibition. Selanjutnya Pemerintah berperan dalam mendukung berlangsungnya perkembangan pameran virtual, dan pembuatan undang-undang yang membahas mengenai virtual event. Pemerintah juga diharapkan dapat menyediakan jangkauan internet secara merata agar kegiatan ini bisa dinikmati oleh berbagai kalangan di penjuru negara. Terakhir adalah konsumen pariwisata, pada proses implementasi ini konsumen dapat berkontribusi dalam pemasaran aplikasi virtual exhibition dengan cara ikut hadir dan meramaikan adanya kegiatan pameran virtual. Sehingga diharapkan dapat menceritakan pengalamannya kepada orang lain, dan membuat orang lain ikut tertarik untuk menghadiri kegiatan pameran virtual.

Dalam proses implementasi juga diperlukan langkah-langkah yang dapat mendukung terlaksananya konsep gagasan yang dibuat, diantaranya:

a. Tahap 1 : Membuat rancangan pengembangan implementasi teknologi VR 360 pada aplikasi virtual exhibition. b. Tahap 2 : Mewujudkan konsep rancangan yang telah di buat dengan adanya dukungan dari pemerintah, pelaku sektor MICE, dan para ahli bidang IT. Pada tahap pembuatan dapat didukung dengan adanya alat seperti google cardboard serta pengembangan aplikasi pameran virtual dengan teknologi VR360.

c. Tahap 3 : Mengenalkan aplikasi kepada seluruh masyarakat, utamanya pelaku industri MICE.

d. Tahap 4 : Mengadakan pelatihan bagi pelaku industri MICE, khususnya virtual exhibition mengenai penggunaan platform pameran virtual berbasis VR 360 .

e. Tahap 5 : Pemerintah mensosialisasikan aplikasi pameran virtual berbasis VR 360 sebagai produk wisata yang dapat menjadi alternatif pilihan masa depan, khususnya dalam industri MICE.

Penggunaan konsep VR 360 ini, dapat menjadikan sebuah pameran virtual terasa semakin nyata dan dapat meningkatkan daya tarik pasar untuk mengunjungi kegiatan virtual exhibition. Selain itu, karena pameran bersifat virtual maka dapat lebih mudah menjangkau konsumen yang terhalang oleh jarak bahkan hingga ke negara lain sekalipun.

\section{KESIMPULAN DAN REKOMENDASI}

Menurunnya minat wisata di masa Covid19 utamanya dalam kegiatan MICE, membuat para ahli dibidang ini memutar otak untuk menemukan alternatif lain dalam upaya mempertahakan bisnis di masa pandemi. Kemajuan teknologi informasi membantu upaya dalam terwujudnya kegiatan agar tetap terlaksana secara online meski dalam situasi pandemi. Dengan terbentuknya aplikasi pameran virtual seperti EventXtra dan Virtualevent.id, menjadi sebuah peluang baru untuk terus mengembangkan aplikasi ini hingga dapat menjadi sebuah kebiasaan atau tren di masa depan dalam penggunaannya. Teknologi informasi saat ini sangat cepat berkembang dan berubah, sehingga bukan hal yang mustahil apabila dalam pengembangan virtual exhibition di masa depan menggunakan sistem Virtual Reality 360 sebagai inovasi di bidang virtual event. Apalagi dengan adanya dukungan alat seperti google cardboard yang sudah dapat dijangkau untuk dimiliki, membuat semakin besarnya peluang inovasi ini dapat dikembangkan lebih lanjut. Adanya sebuah adaptasi baru ini dapat menghasilkan pengalaman yang lebih menarik dalam pelaksanaan pameran 
virtual, karena sistem VR 360 ini membantu konsumennya berfantasi dalam kegiatan bisnis. Dengan adanya pengembangan aplikasi ini, diharapkan kedepannya virtual exhibition dapat menjadi fokus utama penyelenggaraan pameran, bukan hanya sebagai alternatif di masa pandemi.

Hadirnya implementasi pengembangan teknologi pariwisata ini harus selaras dengan adanya kerjasama antar pemerintah dan pelaku industri pariwisata, sehingga diharapkan agar seluruh sektor yang terlibat dalam kegiatan MICE dapat mendukung adanya adaptasi teknologi yang menghasilkan inovasi dalam pengembangan virtual exhibition. Berbagai jenis dukungan dapat dilakukan, seperti mengadakan pelatihan penggunaan aplikasi, pemanfaatan aplikasi yang sudah ada oleh para pelaku MICE, pembuatan undang-undang mengenai virtual event oleh pemerintah hingga pengembangan dalam aplikasi virtualnya itu sendiri.

\section{DAFTAR PUSTAKA}

Aditya, N. R. (2020) Wishnutama Tertarik Ide Garap MICE Online Usai Corona, Apa Tanggapan Industri MICE, travel.compas.com. Available at: https://travel.kompas.com/read/2020/04/05 /120100827/wishnutama-tertarik-idegarap-mice-online-usai-virus-corona-apatanggapan?page=all (Accessed: 19 September 2020).

Aulia, F. N. (2020) Kultural ID Virtual Exhibition, Digelar Untuk Lestarikan Dongeng dan Cerita Rakyat, lingkarkediri.pikiranrakyat. Available rakyat.com/hiburan/pr-67871019/kulturalid-virtual-exhibition-digelar-untuklestarikan-dongeng-dan-cerita-rakyat (Accessed: 10 November 2020).

Beribe, B. S. (2020) EventXtra, Startup Hong Kong yang Mengubah Krisis Pengadaan Event di Masa Corona, akurat.co. Available at: https://akurat.co/iptek/id1144624-read-eventxtra-startup-hongkong-yang-mengubah-krisis-pengadaanevent-di-masa-corona (Accessed: September 2020).

Khoon, L. C. and Ramaiah, C. K. (2008) 'An Overview of Online Exhibitions', DESIDOC Journal of Library \& Information Technology, 28(4), pp. 7-21. doi: 10.14429/djlit.28.4.193.

Kompas.com (2014) Asyiknya Menjajal Kacamata Kardus Google, tekno.kompas.com. Available at: https://tekno.kompas.com/read/2014/07/14 /12330007/Asyiknya.Menjajal.Kacamata. Kardus.Google?page=all (Accessed: 1 November 2020).

Nurcahyadi, G. (2020) Startup Ini Hadirkan Solusi Virtual Industri MICE di Masa Pandemi, mediaindonesia.com. Available at:

https://mediaindonesia.com/read/detail/322 067-startup-ini-hadirkan-solusi-virtualindustri-mice-di-masa-pandemi (Accessed: 11 September 2020).

Pendit, N. (1999) Wisata Konvensi, Potensi Gede Bisnis Besar. Jakarta: PT.Gramedia Pustaka Utama.

Priambo, A. R. (2020) Bosen di Rumah Terus? Intip Liburan Virtual Destinasi Indonesia Aja Yuk!, www.guideku.com. Available at: https://www.guideku.com/travel/2020/04/0 8/210000/bosen-di-rumah-terus-intipliburan-virtual-destinasi-indonesia-aja-yuk (Accessed: 20 September 2020).

Putra, E. Y., Wahyudi, A. and Tumilaar, A. (2018) 'Virtual Reality 360 Interactive Digital Tour of Tomohon City with Stereoscopic Views', Cogito Smart Journal, 4(1), pp. 104-112. Available at: http://cogito.unklab.ac.id/index.php/cogito/ article/view/106.

Shofihara, I. J. (2020) Hadapi "New Normal", Kemenparekraf Harapkan Industri MICE Antisipasi Perubahan, travel.kompas.com. Available

at: https://travel.kompas.com/read/2020/06/03 /145514227/hadapi-new-normalkemenparekraf-harapkan-industri-miceantisipasi-perubahan?page=all (Accessed: 19 September 2020).

Wartaekonomi (2020) Virtualevent.id, Solusi Pameran Secara Virtual, www.wartaekonomi.co.id. Available at: https://www.wartaekonomi.co.id/read3033 79/virtualeventid-solusi-pameran-secaravirtual (Accessed: 16 November 2020). 
Widhiyanto, F. (2020) Aplikasi Virtualevent.id Dilansir Untuk Acara dan Pameran Virtual Artikel ini telah tayang di Investor.id dengan judul 'Aplikasi Virtualevent.id Dilansir Untuk Acara dan Pameran Virtual' Read more at: http://brt.st/6NbxAplikasi Virtualevent.id Dilansir Un, investor.id. Available at: https://investor.id/business/aplikasivirtualeventid-dilansir-untuk-acara-danpameran-virtual.

Wijayaka, B. (2020) Fairtual Gelar New Normal Travel Fair 2020, www.beritasatu.com. Available at:

https://www.beritasatu.com/bernaduswijayaka/nasional/685889/fairtual-gelarnew-normal-travel-fair-2020 (Accessed: 1 November 2020).

XXmorecreative (2020) Virtual exhibition trends with virtual reality technology $V R$, vrtech.com.vn. Available at: https://vrtech.com.vn/virtual-exhibitiontrends-with-virtual-reality-technologyvr/?lang=en (Accessed: 1 November 2020). 